Hidden Talent 
The publisher gratefully acknowledges the generous support of the Lisa See Endowment Fund in Southern California History of the University of California Press Foundation. 


\section{Hidden Talent}

The Emergence of Hollywood Agents

TOM KEMPER

뚜

University of California Press

BERKELEY LOS ANGELES LONDON 
University of California Press, one of the most distinguished university presses in the United States, enriches lives around the world by advancing scholarship in the humanities, social sciences, and natural sciences. Its activities are supported by the UC Press Foundation and by philanthropic contributions from individuals and institutions. For more information, visit www.ucpress.edu.

University of California Press

Berkeley and Los Angeles, California

University of California Press, Ltd.

London, England

(C) 2010 by The Regents of the University of California

Library of Congress Cataloging-in-Publication Data

Kemper, Tom.

Hidden talent : the emergence of Hollywood agents / Tom Kemper. p. $\quad \mathrm{cm}$

Summary: This is a history of Hollywood agents as they rose in the studio system in the late 1920s and early 1930s up through the 1940s, demonstrating the central role they played in the classical Hollywood period.

Includes bibliographical references and index.

ISBN 978-0-520-25706-1 (cloth : alk. paper)

ISBN 978-0-520-25707-8 (pbk. : alk. paper)

1. Theatrical agents-California-Los Angeles-History-2oth century. 2. Theatrical agencies-California-Los Angeles-History2oth century. 3. Motion picture industry-California—Los Angeles-History-2oth century. I. Title.

PN1993.5.U65K36 2009

338.4'7791430979494-dc22 2008054360

Manufactured in the United States of America

$\begin{array}{llllllllll}19 & 18 & 17 & 16 & 15 & 14 & 13 & 12 & 11 & 10\end{array}$

$\begin{array}{llllllllll}10 & 9 & 8 & 7 & 6 & 5 & 4 & 3 & 2 & 1\end{array}$

This book is printed on Natures Book, which contains $30 \%$ postconsumer waste and meets the minimum requirements of ANSI/NISO Z39.48-1992 (R 1997) (Permanence of Paper). 